\title{
Production of Quail Chimeras by Transfer of Early Blastoderm Cells: Plumage Chimeras and a Germline Chimera without Plumage Mixture
}

\author{
Tamao Ono, Shin-ichi Muto*, Takashi Matsumoto and Motokazu Yoshida \\ Faculty of Agriculture, Shinshu University, Ina, 399-45 \\ * Kissei Pharmaceutical Co. Ltd., Matsumoto, 399
}

\begin{abstract}
Dispersed blastoderm cells taken from the unincubated quail eggs were microinjected into the blastoderms of the other unincubated quail eggs. The transfer was performed with the following four kinds of strain combinations, i.e., (1) from the wildtype plumage (WP) to the sex-linked albino (AL), (2) from WP to the black (D), (3) from AL to WP and (4) from D to WP strains. The embryos thus treated were cultured in vitro with the previously reported protocol (ONO et al., Jpn. Poult. Sci., 31 : 119-129, 1994). In the WP to AL combination 50 hatchlings were obtained out of 193 treated embryos (hatchability : 25.9\%). Among them 3 were somatic chimeras as judged by the pigmentation patterns of down feathers. In addition, 13 dead embryos were also plumage chimeras, therefore, 16 out of all treated embryos $(8.3 \% ; 16 / 193)$ became plumage chimeras. However, the other three combinations failed to produce any plumage chimeras $(0 /$ 191). In the D to WP combination 27 hatchlings were obtained out of 83 treated embryos (hatchability : $32.5 \%$ ). Among them 14 survived to maturity and were progeny-tested by mating with WP quail, one male yielded 50 heterozygous and 67 wild-type plumage offsprings, revealing itself as a germline chimera.
\end{abstract}

(Jpn. Poult. Sci., 32 : 252-256, 1995)

Key words : germline chimera, somatic chimera, embryo culture, quail, progeny test

\section{Introduction}

Gene and cell transfer techniques will serve as a powerful tool for the genetic improvement of livestocks, and production of useful materials. PetiTte et al. (1990) reported that dispersed blastoderm cells taken from chick embryos of Stage X (EYALGILADI and Kochav, 1976) could be transferred successfully to another embryo and the transferred cells entered somatic and germ cell lines of the host embryo. The newly laid and unincubated egg is accessible to the population of cells that differentiate into the cell lineage of gametes, and this process can be performed without sacrificing the mother. The resulting animals are chimeras that carry the donor cell line and may produce the donor derived progeny if the donor cells differentiate to the gametes. Chickens have been widely used for the study of transgenesis in poultry. However, Japanese quail may serve as better experimental animal for the transgenesis because of its small body size, fast growth rate and short generation interval. Recently, we developed an in vitro culture method of quail embryos from the single-cell or the blasoderm stages to hatching (ONO et al., 1994a ; 1994b) and produced quail somatic chimeras by applying this culture method (ONo et al., 1994b). In the present study we 
produced the somatic and germline chimeras in quail by transfer of early blastoderm cells. The former was plumage chimeras and the latter was a germline chimera showing no mixture of plumage characters.

\section{Materials and Methods}

\section{Quail}

Quail of the sex-linked albino (AL : homozygous for the sex-linked albino gene, $a l$ ), the black (D : homozygous for the autosomal incomplete dominant gene, $D$ ) and the wild-type plumage (WP) strains, maintained in our laboratory were used (SomEs, 1988 ; Cheng and Kimura, 1990). Birds were kept in an animal room at $22 \pm 2^{\circ} \mathrm{C}$ and under a 14 L-10D light cycle (lighting on at $02: 00$ and off at 16:00). Food and water were available ad libitum.

\section{Cell Transfer for Production of Chimera}

The combination of donor and host strains was as follows, i.e., (1) from WP to AL, (2) from WP to D, (3) from AL to WP and (4) from D to WP. In the present report, strain combination of cell transfer is indicated by the symbol such as $\mathrm{WP} \rightarrow \mathrm{AL}$. The cell transfer was performed according to ONO et al. (1994b). The chimeric embryos were cultured in vitro according to the protocol developed by ONo et al. (1994a; 1994b). Somatic chimerism was examined by pigmentation patterns of the down feathers for the embryos after 12 days of culture and hatchlings.

\section{Progeny Test}

In the present study, the quail derived from the embryos with cell transfer but not showing feather chimerism were treated as putative chimeras. The progeny test was performed for the putative chimeric quail from $\mathrm{D} \rightarrow \mathrm{WP}$ combination. The hatchlings from the embryos with cell transfer were raised to mature and mated with WP. The female partners were either virgins or kept only with females at least 4 weeks and never mated with the males other than WP. The mating partners were changed at least 3 times. For the putative chimeras from the other three combinations the progeny test was not performed because of the limited number of cages available.

\section{Results and Discussion}

\section{Hatchabilities of Cultured Quail Embryos}

Table 1 shows the hatchabilities of the three strains of quail, WP, D and AL, in the normal incubation and in culture with or without cell injection. Good hatchabilities were obtained in the normal incubation from WP and D, being 86.7 and $77.8 \%$, respectively. But that of $\mathrm{AL}(53.3 \%)$ was inferior to these two strains. The low hatchability of AL may be attributed to two factors causing depression of viability, i.e., inbreeding in the course of strain establishment and the albino gene (SomEs, 1988 ; ONO et al., 1994b). The hatchabilities of the non-injected cultured embryos were lowered by $15-40 \%$ compared with the corresponding normal incubation. Furthermore, the hatchabilities of the embryos with cell transfer were reduced by $10-20 \%$ as compared with the non-injected culture embryos. However, the hatchabilities of over $25 \%$ were yielded in all four transfer combinations. 


\section{Somatic and Germline Chimeras}

The somatic chimeras as judged by the pigmentation patterns of down feathers were observed only in $\mathrm{WP} \rightarrow \mathrm{AL}$ combination (Table 1). In other words it was observed only in the case that the melanin synthesizing cells were transferred to the non-synthesizing hosts. The cells of AL strain may be less viable than the other melanin synthesizing cells. The chimeric expression of down feathers was observed in the whole body but it was most frequently observed at head region. This finding was common to the chick-chick (MARzullo, 1970 ; PetitTe et al., 1990) and chick-quail chimeras (NAITO et al., 1991 ; WATANABE et al., 1992). Out of 16 chimeric quail 13 died before hatching and 3 died within 2 days after hatching. No plumage chimeras were found in dead embryos and hatchlings from the other three combinations. However, there remained a possibility that they might be chimeric in the tissue or organs other than the skin, and they were treated as putative chimeras as mentioned previously.

For the putative chimeras from $\mathrm{AL} \rightarrow \mathrm{WP}, \mathrm{WP} \rightarrow \mathrm{D}$ and $\mathrm{WP} \rightarrow \mathrm{AL}$ combinations we did not conduct the progeny test because the enough cages for the test were not available. For those from $\mathrm{D} \rightarrow \mathrm{WP}$ combinations 10 males and 4 females grew up to maturity and they were mated with WP partners (Table 2). The female WP partners mated with one putative male chimera produced 117 hatchlings in total. The 50 were $\left[D / d^{+}\right]$heterozygous hatchlings derived from the donor gametes and 67 were $\left[d^{+} / d^{+}\right]$ wild-type plumage hatchlings derived from the host gametes. Thus, this individual was proved to be a germline chimera. But the production rate of the germline

Table 1. Hachabilities of the quail embryos injected with alien blastoderm cells and chimerism of the resulting embryos, hatchlings and adult quail

\begin{tabular}{|c|c|c|c|c|}
\hline \multirow{2}{*}{$\begin{array}{l}\text { Strains } \\
\text { of host } \\
\text { embryos }\end{array}$} & \multirow{2}{*}{ Types of treatment } & \multirow{2}{*}{ Hatchability (\%) } & \multicolumn{2}{|c|}{ No. $(\%)$ of quail with chimerism in } \\
\hline & & & down feathers & germ cells \\
\hline \multirow{4}{*}{ WP } & Normal incubation & $26 / 30 \quad(86.7 \%)$ & \multirow{4}{*}{$\mathrm{N} / \mathrm{A}^{3)}$} & \\
\hline & Culture & $30 / 62 \quad(48.4 \%)$ & & \\
\hline & D cells injection and culture & $27 / 83 \quad(32.5 \%)$ & & $1^{4)}(1.2 \%)^{5)}$ \\
\hline & AL cells injection and culture & $16 / 57 \quad(28.1 \%)$ & & N.D. ${ }^{6)}$ \\
\hline \multirow{3}{*}{$\mathrm{D}$} & Normal incubation & $21 / 27 \quad(77.8 \%)$ & \multirow{3}{*}{$\mathrm{N} / \mathrm{A}$} & \\
\hline & Culture & $20 / 52 \quad(38.5 \%)$ & & \\
\hline & WP cells injection and culture & $13 / 51 \quad(25.5 \%)$ & & N.D. \\
\hline \multirow{3}{*}{$\mathrm{AL}$} & Normal incubation & $16 / 30 \quad(53.3 \%)$ & \multirow{3}{*}{$\mathrm{N} / \mathrm{A}$} & \\
\hline & Culture & $26 / 70 \quad(37.1 \%)$ & & \\
\hline & WP cells injection and culture & $50 / 193(25.9 \%)$ & & N.D. \\
\hline
\end{tabular}

1) Out of 16 chimeric quail 13 died before hatching and 3 died within 2 days after hatching.

2) Percentage of chimeric quail before and after hatching against number of embryos injected.

3) Not applicable.

4) Fourteen putative chimeras were mated with WP partners and the female WP partners mated with one putative chimera produced hatchlings derived from donor gametes (see Table 2).

5) Percentage of chimeric quail against number of embryos injected.

6) Progeny test was not done. 
ONO et al. : Somatic and Germline Chimeras in Quail

Table 2. Progeny test of $\mathrm{D} \rightarrow \mathrm{WP}$ putative chimeras ${ }^{1)}$

\begin{tabular}{|c|c|c|c|}
\hline \multirow{2}{*}{$\begin{array}{l}\text { Sex of } \\
\text { putative } \\
\text { chimera }\end{array}$} & \multicolumn{2}{|c|}{ No. of progenies derived from } & \multirow{2}{*}{$\begin{array}{l}\% \text { of chimerism in } \\
\text { germ cells }\end{array}$} \\
\hline & host germ cells & donor germ cells & \\
\hline$\sigma^{7}$ & $67^{2)}$ & $50^{3)}$ & $42.7 \%$ \\
\hline$\sigma^{\pi}$ & 142 & 0 & $0.0 \%$ \\
\hline$\sigma^{\pi}$ & 120 & 0 & $0.0 \%$ \\
\hline$\sigma^{7}$ & 90 & 0 & $0.0 \%$ \\
\hline$\sigma^{7}$ & 88 & 0 & $0.0 \%$ \\
\hline$\sigma^{7}$ & 63 & 0 & $0.0 \%$ \\
\hline$\sigma^{\pi}$ & 60 & 0 & $0.0 \%$ \\
\hline$\sigma^{7}$ & 11 & 0 & $0.0 \%$ \\
\hline$\sigma^{7}$ & 11 & 0 & $0.0 \%$ \\
\hline$\sigma^{7}$ & 9 & 0 & $0.0 \%$ \\
\hline 우 & 115 & 0 & $0.0 \%$ \\
\hline 우 & 102 & 0 & $0.0 \%$ \\
\hline 우 & 102 & 0 & $0.0 \%$ \\
\hline 우 & 80 & 0 & $0.0 \%$ \\
\hline
\end{tabular}

1) $\mathrm{D} \rightarrow$ WP putative chimeras at 2-7 months of age were mated to WP partners. For abbreviation of the strain name and the symbol showing cell transfer for chimera production, see text.

2) Wild-type plumage quail resulting from $\mathrm{WP} \times \mathrm{WP}$ germ cells.

3) Heterozygous dominant black plumage quail resulting from $\mathrm{D} \times \mathrm{WP}$ germ cells.

chimeras was very low as compared with the studies in the chicken in which the host embryos were compromised by $\gamma$ irradiation before transfer (CARSIENCE et al., 1993) or the concentrated primordial germ cells were directly transferred into the bloodstream at early developmetal stages (Naito et al., 1994).

The somatic and germline chimeras in the present study may include sex chimeras in which male and female cells are mixed. Unfortunately we did not examine the ratio of male and female cells in the donor samples, the sex ratio of hatchlings, the gonads of chimeras, etc. It is interesting to investigate in avian species how development of gonads is influenced by mixing with germ cells or somatic cells of opposite sexes. We showed recently that quail primordial germ cells can survive in the chick gonads of the opposite sexes in the early stages of gonad development (ONO and YOKOI, 1994).

\section{Acknowledgments}

This study was supported in part by a Grant-in-Aid from the Ministry of Education, Science and Culture, Japan to T. O. (No.06660351).

\section{References}

Carsience, R.S., M.E. Clark, A.M. Verringer Gibins and R.J. Etches (1993) Germline chimeric chickens from dispersed donor blastodermal cells and compromised recipient embryos. Development, 117 : 669-675.

Cheng, K.M. and M.Kimura (1990) Mutations and major variants in Japanese quail. In 'Poultry Breeding and Genetics (CrawFORD, R.D. ed.)', pp. 333-362. Elsevier, Amsterdam. 
EYAL-GILADI, H. and S. Kochav (1976) From cleavage to primitive streak formation : a complementary normal table and a new look at the first stages of development of the chick. Developmental Biology, 49 : 321-337.

Marzullo, G. (1970) Production of chick chimaeras. Nature, 225 : 72-73.

Naito, M., M. Watanabe, K. Nirasawa and T. Oishi (1991) Production of quail-chick chimaeras by blastoderm cell transfer. British Poulty Science, 32 : 79-86.

Naito, M., A. Tajima, Y. Yasuda and T. Kuwana (1994) Production of germline chimeric chickens, with high transmission rate of donor-derived gametes, produced by transfer of primordial germ cells. Molecular Reproduction and Development, 39 : 153-161.

Ono. T., T. Murakami, M. Mochi, K. Agata, K. Kino, K. Otsuka, M. Ohta, M. Mizutani, M. Yoshida and G. EGUCHI (1994a) A complete culture system for avian transgenesis, supporting quail embryos from the single cell stage to hatching. Developmental Biology, 161 : 126-130.

Ono. T., S. Muto, M. Mizutani, K. Agata, M. Mochil, K. Kino, K. Otsuka, M. Ohta, M. Yoshida and G. EGUCHI (1994b) Production of quail chimera by transfer of early blastodermal cells and its use for transgenesis. Japanese Poultry Science, 31 : 119-129.

ONO, T. and R. YoKOI (1994) Transfer of male and female primordial germ cells of quail into chick embryonic gonad of the same and opposite sexes. Proceeding of the 5 th World Congress on Genetics Applied to Livestock Production, 20 : 104-107.

Petitte, J.N., M.E. Clark, G. Liu, A.M. Verringer Gibbins and R.J. Etches (1990). Production of somatic and germline chimeras in the chicken by transfer of early blastodermal cells. Development, 108 : 185-189.

Watanabe, M., M. Kinutani, M. Naito, O. Ochi and Y. Takashima (1992) Distribution analysis of transferred donor cells in avian blastodermal chimeras. Development, 114 : 331-338.

\title{
胚盤葉細胞注入によるキメラウズラの作出 : 羽装キメラおよび 混合羽装を示さない生殖細胞キメラ
}

\author{
小野珠乙・武藤信一 ${ }^{*} \cdot$ 松本 岳・吉田元一 \\ 信州大学農学部 長野県南箕輪村 399-45 \\ *現所属(株)キッセイ薬品工業 松本市 399
}

\begin{abstract}
ウズラ肧の肧盤葉細胞を羽装の異なるウズラ肧に注入 しキメラの作出を試みた。使用した系統は野生型羽装 (WP), 性染色体性劣性アルビノ( AL), および常染色体 性不完全優性黒色羽装(D)で次の 4 種の組み合わせによ り細胞注入を行なった：(1) WP $\rightarrow \mathrm{AL},(2) \mathrm{WP} \rightarrow \mathrm{D}$, (3) $\mathrm{AL} \rightarrow \mathrm{WP}$, (4) $\mathrm{D} \rightarrow \mathrm{WP}$ 。処置したホスト胚は ONoet al. (Jpn. Poult. Sci., 31 : 119-129, 1994) の in vitro 培養法 で培養し, 粰化させた。WP $\rightarrow$ AL 群においては 193 の注 入胚より 50 羽のヒナが粰化（粰化率 : $25.9 \%$ ）し，その 内 3 羽が羽装キメラであり後期死亡胚においても 13 が
\end{abstract}

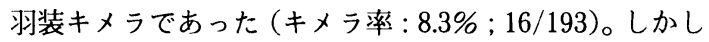
他の 3 群では羽装キメラは発現しなかった (0/191)。D $\rightarrow W P$ 群においては 83 の注入胚より 27 羽のヒナが粰化 （躬化率 : $32.5 \%$ ）し，性成熟に達した 14 羽をWP と交 配した。それらの内, 1 羽の雄は 117 羽の子孫を生産し, その中 50 羽が $\left[D / d^{+}\right]$ヘテロ型羽装であり, 生殖細胞キ メラであることが判明した。

（家禽会誌, 32:252-256, 1995)

キーワード : 生殖細胞キメラ, 体細胞キメラ, 肧培養, ウズラ, 後代検定 